\title{
A randomized study comparing rectally administered misoprostol after spinal anesthesia versus intramuscular oxytocin for prevention of postpartum hemorrhage in caesarean section
}

\author{
Madhuri Alwani*, Swapnil Singh, Ratna Thakur, Sunita Mishra
}

Department of Obstetrics and Gynaecology, Sri Aurobindo Medical College and PG Institute, Indore-453111, Madhya Pradesh, India

Received: 24 May 2014

Accepted: 10 June 2014

\section{*Correspondence:}

Dr. Madhuri Alwani,

E-mail: drmadhuri_2007@rediffmail.com

(C) 2014 Alwani M et al. This is an open-access article distributed under the terms of the Creative Commons Attribution Non-Commercial License, which permits unrestricted non-commercial use, distribution, and reproduction in any medium, provided the original work is properly cited.

\begin{abstract}
Background: Post-Partum Hemorrhage (PPH) is the commonest cause of maternal death worldwide. Studies suggest that the use of Misoprostol may be beneficial in clinical settings where oxytocin is unavailable. However studies are limited that show its use in prevention of PPH in high risk pregnancy involving elective caesarean section. Therefore our aim of study is to compare the effectiveness of rectal misoprostol with intramuscular oxytocin in the prevention of postpartum hemorrhage in cesarean sections.

Methods: In a double-blind randomized controlled trial, 200 pregnant women who had cesarean sections were assigned into two groups: to receive either oxytocin intramuscularly or misoprostol rectally after spinal anesthesia.

Results: There was no significant difference between the two groups about change in postpartum hemoglobin, need for blood transfusion and incidence of PPH. We also did not observe any significant difference in any side effects.

Conclusions: Misoprostol may be considered as an alternative for oxytocin in low resource clinical settings.
\end{abstract}

Keywords: Postpartum Hemorrhage, Misoprostol, Oxytocin

\section{INTRODUCTION}

Despite great advances in medical therapies and surgical techniques in recent decades, Post-Partum Hemorrhage $(\mathrm{PPH})$ remains an important medical issue for both developing and developed countries. ${ }^{1}$ The incidence of $\mathrm{PPH}$ has been estimated to range from $1.47-18 \%$ of all deliveries, depending on the definition and criteria that are used ${ }^{1-3}$ and on the regions or countries concerned. ${ }^{4}$

With approximately 500-1000 $\mathrm{ml} / \mathrm{min}$ blood flow, which comprises approximately $17 \%$ of cardiac output that perfuses the maternal uterus at term, ${ }^{5}$ cesarean section (CS) delivery inevitably results in significant blood loss before the uterine musculature can contract around uterine spiral arteries.
The primary cause of $\mathrm{PPH}$ is uterine atony which accounts for $70 \%$ of cases leading to severe postnatal anemia and hemorrhagic shock requiring transfusions and surgical interventions. ${ }^{6,7}$ Therefore Oxytocin which is uterotonic agents is used as effective first-line treatment for postpartum hemorrhage. Oxytocin stimulates the upper segment of the myometrium to contract rhythmically, which constricts spiral arteries and decreases blood flow through the uterus. ${ }^{8}$

Misoprostol is a synthetic PGE1 analog, also has uterotonic properties and it is one of the most useful drugs in obstetrics. ${ }^{9}$ The drug is low cost and stable at room temperature. Ease of its administration through various routes, and safety profile make it a good option in resource-poor settings, ${ }^{9-11}$ and in patients who are 
vomiting, unable to take medications, or under anesthesia.

Various studies have been performed for comparing the efficacy and side effects of these two drugs in low risk pregnancy and normal vaginal delivery cases. ${ }^{12-16}$ However studies involving patients with cesarean section are limited. Therefore, the aim of the present study is to compare the effect of preoperative administration of rectal misoprostol after spinal anesthesia versus intramuscular oxytocin in prevention of PPH in cesarean section in high-risk pregnancy.

\section{METHODS}

\section{Subjects}

This randomized prospective study was performed between Jun 2011 and April 2012 on high risk pregnant women coming at labor room of department of obstetrics and gynaecology, Sri Aurobindo institute of medical sciences, Indore.

Total of 200 women of high risk pregnancy were included undergoing caesarean section in whom PostPartum Hemorrhage (PPH) was anticipated. Women were counseled about their participation in the study. Written informed consent was obtained before cesarean section.

The patients were randomized in two groups using random number table generated online (http://www.graphpad.com/quickcalcs/randomize1/). In group A, women taken up for cesarean section were given preoperatively tablet misoprostol 600 microgram per rectum after spinal anesthesia before painting and draping was done. In group B, women were given inj. oxytocin $10 \mathrm{IU}$ intramuscularly after the baby was extracted out in cesarean section.

Hemoglobin level was measured before and 24 hour after the operation. Shivering, number of nausea and vomiting along the operation and up to 2 hours after it was recorded. Temperature was monitored routinely and noted in the data sheet when greater than $37.5^{\circ} \mathrm{C}$.

Statistical analysis was done on SPSS 20.0 software. Chi square test was used to see the difference in categorical data whereas student $\mathrm{t}$ test was used to see the difference in continuous variables in two groups. $\mathrm{P}$ value of $<0.05$ was considered statistically significant.

\section{RESULTS}

The mean age of the study participants in group A and B were $25.7 \pm 3.2$ and $25.8 \pm 4.1$ years respectively. There was no significant difference between the groups regarding baseline characteristics or risk factors for postpartum hemorrhage (Table 1). The incidence of PPH in group A and group B was 3.0 and $2.0 \%$ respectively

We found no significant difference between the groups for change in hemoglobin concentration. There was also no significant difference in postpartum haemoglobin and need for blood transfusion in both the groups (Table 2). There was one maternal death in oxytocin group (Table 2). The use of additional uterotonic agents was less in group A as compared to group B with a relative risk of 0.59 (95\% CI 0.2620-1.371); however the difference was statistically insignificant ( $\mathrm{P}$ value 0.2507 ).

Table 1: Demographic characteristics and risk factors of PPH in two groups.

\begin{tabular}{|llll|}
\hline Parameter & $\begin{array}{l}\text { Group A } \\
\text { (Misoprostol) }\end{array}$ & $\begin{array}{l}\text { Group B } \\
(\text { Oxytocin) }\end{array}$ & P value \\
\hline Maternal Age & $25.7 \pm 3.2$ & $24.9 \pm 4.1$ & 0.1256 \\
\hline Gravida & $2[1-4]$ & $2[1-4]$ & - \\
\hline Parity & $1[0-3]$ & $1[0-3]$ & - \\
\hline Gestation in weeks & $37.1 \pm 1.2$ & $36.9 \pm 2.3$ & 0.4417 \\
\hline PPH Risk factors & & & \\
\hline $\begin{array}{l}\text { Pregnancy induced } \\
\text { hypertension }\end{array}$ & 23 & 20 & 0.7310 \\
\hline $\begin{array}{l}\text { Ante partum } \\
\text { haemorrhage } \\
\text { (abruptio placenta) }\end{array}$ & 08 & 06 & 0.7828 \\
\hline Placenta previa & 06 & 08 & 0.7828 \\
\hline Grand multipara & 04 & 07 & 0.5371 \\
\hline $\begin{array}{l}\text { Anaemia in } \\
\text { pregnancy }\end{array}$ & 16 & 17 & 1.000 \\
\hline Polyhydramnios & 10 & 12 & 0.8217 \\
\hline Twin pregnancy & 08 & 07 & 1.000 \\
\hline Big size baby & 05 & 06 & 1.000 \\
\hline $\begin{array}{l}\text { Jaundice with } \\
\text { pregnancy }\end{array}$ & 02 & 01 & 1.000 \\
\hline $\begin{array}{l}\text { Obstructed labor } \\
\text { Prolonged labor }\end{array}$ & 06 & 04 & 0.7475 \\
\hline $\begin{array}{l}\text { Fibroid with } \\
\text { pregnancy }\end{array}$ & 02 & 12 & 0.8217 \\
\hline
\end{tabular}

Table 2: Outcome measures indicative of blood loss.

\begin{tabular}{|lllll|}
\hline Parameters & $\begin{array}{l}\text { Group A } \\
\text { (Misoprostol) }\end{array}$ & $\begin{array}{l}\text { Group B } \\
\text { (Oxytocin) }\end{array}$ & $\begin{array}{l}\text { P value } \\
\text { Change in } \mathrm{Hb}\end{array}$ & $\begin{array}{l}\text { Relative risk } \\
(\mathbf{9 5} \% \mathrm{CI})\end{array}$ \\
\hline Postpartum haemoglobin & $10.3 \pm 1.31$ & $1.12 \pm 0.9$ & 0.6513 & - \\
\hline Additional uterotonic agent & 4 & $10.7 \pm 2.1$ & 0.0998 & - \\
\hline Need for Blood transfusion & 2 & 9 & 0.2507 & $0.55(0.262-1.371)$ \\
\hline Maternal Mortality & 0 & 5 & 0.448 & $0.56(0.1729-1.831)$ \\
\hline
\end{tabular}


Table 3 shows that there was no significant difference in incidence of side effects namely shivering, nausea, vomiting, hypertension and temperature $>37^{\circ} \mathrm{C}$. Although there was no significant difference in incidence of shivering in both the groups but the high relative risk (1.806, 95\% CI 1.338-2.438) suggests shivering as a side effect of misoprostol.

Table 3: Side effects encountered in both groups.

\begin{tabular}{|llll|}
\hline Parameters & $\begin{array}{l}\text { Group A } \\
\text { (Misoprostol) }\end{array}$ & $\begin{array}{l}\text { Group B } \\
\text { (Oxytocin) }\end{array}$ & P value \\
\hline Nausea & 1 & 2 & 1.000 \\
\hline Vomiting & 1 & 1 & 1.000 \\
\hline Shivering & 7 & 1 & 0.0649 \\
\hline Temperature & 4 & 2 & 0.682 \\
\hline Hypertension & 1 & 0 & - \\
\hline
\end{tabular}

\section{DISCUSSION}

We compared the administration of rectal misoprostol with an intramuscular injection of oxytocin as part of the routine active management of $\mathrm{PPH}$ in the caesarean section. The outcomes of both groups were comparable and misoprostol was as effective as oxytocin in reducing the incidence of PPH.

Our study is similar to study done by Fazel et al. from Iran $^{17}$ and Chaudhary et al. from India. ${ }^{18}$ Other studies involving low risk pregnancy shows conflicting results. Chong et al. ${ }^{9}$ concluded that the drug was not as successful as expected. Studies from low-resource settings ${ }^{10,19}$ considered the drug to be a low-cost, easy, and comparable option to oxytocin, ${ }^{11,18-21}$ oxytocin and ergot preparations, ${ }^{22,23}$ or prostaglandin F2- $\alpha .{ }^{24}$ Shivering was observed in $7 \%$ of cases in misoprostol group an 1 $\%$ in oxytocin group in our study. Vimala et al. ${ }^{19}$ has reported shivering in $26 \%$ of patients with $400 \mu \mathrm{g}$ of sublingual misoprostol, and $4 \%$ in oxytocin group. Chaudhuri et al. ${ }^{18}$ reported $8.3 \%$ and $1.1 \%$ in the misoprostol and oxytocin groups respectively The discrepancy in incidence of shivering may be due to use of different methods for administration of drugs, kind of anesthesia, temperature of the operation room, and fluids used during the procedure.

In conclusion, to substitute for oxytocin and to prevent postpartum hemorrhage in cesarean sections misoprostol can be used as it has similar advantages but with minimal side effects, low shelf life, inexpensive and easily available. It is easy to use and does not require special storage conditions (i.e., can be stored easily at room temperature; is thermo stable and light stable; does not require specific conditions for transfer) and has a shelf life of several years.

\section{Funding: No funding sources} Conflict of interest: None declared

Ethical approval: The study was approved by the institutional ethics committee

\section{REFERENCES}

1. Devine PC. Obstetric haemorrhage. Semin Perinatol. 2009;33:76-81.

2. Magann EF, Evans S, Hutchinson M, Collins R, Howard BC, Morrison JC. Postpartum haemorrhage after vaginal birth: an analysis of risk factors. South Med J. 2005;98:419-22.

3. Magann EF, Evans S, Hutchinson M, Collins R, Lanneau G, Morrison JC. Post-partum haemorrhage after cesarean delivery: an analysis of risk factors. South Med J. 2005;98:681-5.

4. Al-Zirqi I, Vangen S, Forsen L, Stray-Pedersen B. Prevalence and risk factors of severe obstetric haemorrhage. BJOG. 2008;115:1265-72.

5. Gant NF, Worley RJ. Measurement of uteroplacental blood flow in the human. In: Rosenfeld CR, Cox BE, Roy T, Ronald R, eds. The Uterine Circulation. Ithaca, NY: Perinatology Press; 1989: 53-73.

6. Rojers J, Wood J, McCandlish R, Ayers S, Trusdale A, Elbourne D. Active versus expectant management of third stage of labor: the Hinchinbrook randomised controlled trial. Lancet. 1998;39:693-9.

7. Khan Go, John Wanies, Doberty T, Sibai MB. Controlled cord traction versus minimal intervention techniques in delivery of placenta: a randomized controlled trial. Am J Obstet Gynaecol 1997;177:770-4.

8. Blanks AM, Thornton S. The role of oxytocin in parturition. BJOG. 2003;110(Suppl 20):46-51.

9. Chong YS, Su LL, Arulkumaran S. Misoprostol: a quarter century of use, abuse, and creative misuse. Obstet Gynaecol Surv. 2004;59(2):128-40.

10. Derman RJ, Kodkany BS, Goudar SS, Geller SE, Naik VA, Bellad MB et al. Oral misoprostol in preventing postpartum haemorrhage in resource-poor communities: a randomized controlled trial. Lancet. 2006;368(9543):1248-53.

11. Gupta B, Jain V, Aggarwal N. Rectal misoprostol versus oxytocin in the prevention of postpartum haemorrhage: a pilot study. Int J Gynaecol Obstet. 2006;94(Suppl 2):S139-40.

12. Gerstenfeld TS, Wing DA. Rectal misoprostol versus intravenous oxytocin for the prevention of postpartum hemorrhage after vaginal delivery. Am J Obstet Gynaecol. 2001;185(4):878-82.

13. Nasr A, Shahin AY, Elsamman AM, Zakherah MS, Shaaban OM. Rectal misoprostol versus intravenous oxytocin for prevention of post-partum haemorrhage. Int J Gynaecol Obstet. 2009 Jun;105(3):244-7.

14. Shrestha A, Dongol A, Chawla CD, Adhikari RK. Rectal misoprostol versus intramuscular oxytocin for prevention of post-partum hemorrhage. Kathmandu Univ Med J (KUMJ). 2011 Jan-Mar;9(33):8-12.

15. Rajaei M, Karimi S, Shahboodaghi Z, Mahboobi H, Khorgoei T, Rajaei F. Safety and efficacy of misoprostol versus oxytocin for the prevention of postpartum haemorrhage. J Pregnancy. 2014;2014:713879. 
16. Gohil JT, Tripathi B. A study to compare the efficacy of misoprostol, oxytocin, methylergometrine and ergometrine-oxytocin in reducing blood loss in active management of $3^{\text {rd }}$ stage of labor. J Obstet Gynaecol India. 2011 Aug;61(4):408-12.

17. Fazel MR, Mansoure-Samimi, Esmaeil-Fakharian A. Comparison of rectal misoprostol and intravenous oxytocin on hemorrhage and homeostatic changes during cesarean section. Middle East J Anaesthesiol. 2013;22(1):41-6.

18. Chaudhuri P, Banerjee GB, Mandal A. Rectally administered misoprostol versus intravenous oxytocin infusion during cesarean delivery to reduce intraoperative and postoperative blood loss. Int $\mathrm{J}$ Gynaecol Obstet. 2010;109(1):25-9.

19. Vimala N, Mittal S, Kunar S. Sublingual misoprostol versus oxytocin infusion to reduce blood loss at cesarean section. Int $\mathbf{J}$ Gynaecol Obstet. 2006;92(2):106-10.

20. Shojai R, Desbrière R, Dhifallah S, Courbière B, Ortega D, d'Ercole C et al. Rectal misoprostol for postpartum hemorrhage (in French). Gynaecol Obstet Fertil. 2004;32(9):703-7.
21. Baruah M, Cohn GM. Efficacy of rectal misoprostol as second-line therapy for the treatment of primary postpartum haemorrhage. J Reprod Med. 2008;53(3):203-6.

22. Mousa HA, Alfirevic Z. Treatment for primary postpartum haemorrhage. Cochrane Database Syst Rev. 2007;(1):CD003249.

23. Bamigboye AA, Merrell DA, Hofmeyr GJ, Mitchell R. Randomized comparison of rectal misoprostol with Syntometrine for management of third stage of labor. Acta Obstet Gynaecol Scand. 1998;77(2):17881.

24. Nellore V, Mittal S, Dadhwal V. Rectal misoprostol vs. 15-methyl prostaglandin F2 alpha for the prevention of postpartum haemorrhage. Int $\mathbf{J}$ Gynaecol Obstet. 2006;94(1):45-6.

DOI: $10.5455 / 2320-1770 . i j r \operatorname{cog} 20140909$

Cite this article as: Alwani M, Singh S, Thakur R, Mishra S. A randomized study comparing rectally administered misoprostol after spinal anesthesia versus intramuscular oxytocin for prevention of postpartum hemorrhage in caesarean section. Int $\mathbf{J}$ Reprod Contracept Obstet Gynecol 2014;3:512-5. 